\title{
A Note on Sentencing Practices for the Offence of the Unlawful Possession of Semi-Automatic Firearms
}

\section{P.E.R}

Pioneer in peer-reviewed, open access online law publications

Author

Pieter G du Toit

Affiliation

North-West University, South Africa

Email Pieter.duToit@nwu.ac.za

Date Submission

6 April 2019

Date Revised

17 February 2020

Date Accepted

18 February 2020

Date published

17 March 2020

Editor Prof W Erlank

How to cite this article

Du Toit P "Note on Sentencing Practices for the Offence of the Unlawful Possession of SemiAutomatic Firearms" PER / PELJ 2020(23) - DOI

http://dx.doi.org/10.17159/17273781/2020/v23i0a6237

\section{Copyright}

DOI

http://dx.doi.org/10.17159/1727-

3781/2020/v23i0a6237

\begin{abstract}
Violent crimes in South Africa are often accompanied by the possession or use of semi-automatic firearms. The Criminal Law Amendment Act 105 of 1997 (the CLA) provides for the imposition of minimum sentences for certain firearms-related offences. The question whether the minimum sentencing regime actually applies to the offence of the unlawful possession of a semi-automatic firearm has led to a number of conflicting judicial decisions by different High Courts. This note discusses the statutory interpretation challenges the courts had to grapple with regarding the interplay between the CLA and South Africa's successive pieces of firearms legislation. The Supreme Court of Appeal ultimately found that the offence of the unlawful possession of a semi-automatic firearm must indeed be met with the prescribed minimum sentence. The recent sentencing practices of South African courts in respect of the unlawful possession of semi-automatic firearms within the framework of the CLA are analysed. From the investigation it is evident that courts are more likely to impose the minimum sentence in cases where the accused is also convicted of other serious offences such as murder and robbery. In such cases little attention is given to the firearm-related offences as the courts are more concerned with the cumulative effect of the sentences imposed on different counts. In cases where the accused is convicted of the stand-alone offence of the unlawful possession of a semiautomatic firearm, the courts are nevertheless taking an increasingly unsympathetic stance towards offenders, and terms of imprisonment in the range of 7 to 10 years are commonly imposed. In addition to the accused's personal circumstances, one of the most important factors in deciding on an appropriate sentence is the explanation of how the unlawful possession came about. It seems that the judicial sentiment increasingly does not support the view that the possession of an unlicensed firearm should be treated as serious only if the weapon has been used for the commission of a serious crime.
\end{abstract}

\section{Keywords}

Minimum sentencing; semi-automatic firearm; substantial and compelling circumstances. 


\section{Introduction}

Violent crime involving the use of firearms is a matter of grave concern in South Africa. ${ }^{1}$ It has been described as "a very menacing evil". ${ }^{2}$ The Criminal Law Amendment Act 105 of 1997 (hereinafter the CLA) provides for the imposition of minimum sentences for certain offences, including some firearms-related offences. The CLA empowers a Regional Magistrates' Court or a High Court to impose, on a first offender, a minimum sentence of 15 years' imprisonment for any offence in relation to the possession of an automatic or semi-automatic firearm. A second offender of such an offence faces a minimum sentence of 20 years' imprisonment, whilst a third or subsequent offender of such an offence faces 25 years' imprisonment. A Regional Magistrates Court may impose not more than 5 years longer than the minimum sentence prescribed in each instance. ${ }^{3}$ If the court is satisfied that substantial and compelling circumstances exist which justify the imposition of a lesser sentence than the prescribed sentence, it must enter those circumstances on the record of the proceedings and must thereupon impose such a lesser sentence. ${ }^{4}$ Although providing for minimum sentences for firearm-related offences, the CLA makes no reference to the specific statutory provisions criminalising the possession of automatic or semi-automatic firearms. Currently the Firearms Control Act 60 of 2000 (hereinafter the FCA) regulates the possession of firearms. The FCA came into force on 1 July 2004. It repealed and replaced the Arms and Ammunition Act 75 of 1969. Section 3 of the FCA contains a general prohibition on the possession of a firearm without the necessary licence, permit or authorisation. The FCA further provides for a sentence of imprisonment not exceeding 15 years for this offence. ${ }^{5}$ Section 4 of the FCA criminalises the possession of "prohibited firearms", including automatic firearms, being firearms that may not be possessed or licensed in terms of

Pieter Gerhardus du Toit. B luris LLB (UOVS) LLM (UJ) LLD (NWU). Professor, Faculty of Law, North-West University (Potchefstroom Campus), South Africa. Email: Pieter.dutoit@nwu.ac.za.

$1 \quad S$ v Delport 20162 SACR 281 (WCC) para [41]. The court also held at para [36]: "Any person with experience of life in this country from 1970 to the present will be acutely aware that the incidence of the possession of stolen and unlicensed firearms and their use in the commission of violent crime has increased enormously during that period; hence the reference in $\mathrm{s} 2$ of the Firearms Control Act to 'the proliferation of illegally possessed firearms". Also see Witbooi v S 2015 ZAWCHC 185 (8 December 2015) para [14].

$2 \quad S v$ Delport 20162 SACR 281 (WCC) para [37].

3 Section 51(2) read with Part II Schedule 2 of the Criminal Law Amendment Act 105 of 1997 (the CLA).

Section 51(3) of the CLA.

5 Section 121 read with Schedule 4 of the Firearms Control Act 60 of 2000 (the FCA). 
the Act, except in certain exceptional circumstances. The maximum period of imprisonment that may be imposed for this offence is 25 years. ${ }^{6}$ Ordinary Magistrates' Courts, whose general sentencing jurisdiction is limited to three years' imprisonment, ${ }^{7}$ are given enhanced penal jurisdiction and are empowered to impose the sentences provided for in the FCA. ${ }^{8}$ From the penal provisions described above it is clear that the legislature regards the possession of automatic and other prohibited firearms as a more serious offence than the unlawful possession of a semi-automatic firearm. The CLA, however, prescribes a minimum sentence of 15 years' imprisonment for the unlawful possession of both an automatic firearm and a semi-automatic firearm.

With reference to the applicability of the minimum sentence regime to firearm-related offences, the Western Cape High Court stated that "it has been the subject of no little controversy and discordant judicial interpretation by the courts during the last decade or so". ${ }^{9}$ This note focusses on the sentencing of arguably one of the most commonly prosecuted offences in terms of the FCA, namely the possession of a semi-automatic firearm without a licence, permit or authorisation, or simply the "unlawful possession" of such a firearm. A perusal of the many reported and unreported cases that are considered here supports the conclusion that violent crimes such as murder and robbery are often accompanied by the possession or use of semi-automatic firearms. This contribution firstly provides a historical overview of the statutory interpretation challenges the courts had to grapple with regarding the interplay between the CLA and South Africa's successive pieces of firearms legislation. Thereafter the recent sentencing practices of our courts in respect of the unlawful possession of semi-automatic firearms within the framework of the CLA are analysed. The minimum sentencing regime has not eliminated the courts' discretion to impose appropriate sentences and considering all the traditional factors to be taken into account at the sentencing stage. Prescribed minimum sentences, however, remain the benchmark sentences and one of the purposes of the minimum sentencing legislation is to ensure a standardised and consistent response to serious crimes. The question arises whether the courts have succeeded in achieving this aim. In order to properly contextualise the discussion on the relationship between the FCA and the relevant provisions of the CLA, it is necessary to briefly

Section $121 \mathrm{FCA}$ read with Schedule 4 of the FCA.

Section 92(a) of the Magistrates' Court Act 32 of 1944.

Section 151 of the FCA.

$S$ v Delport 20162 SACR 281 (WCC) para [2]. 
refer to the applicability of the CLA to the statutory regime in respect of firearms prior to the coming into operation of the FCA.

\section{The Arms and Ammunition Act of 1969 and the CLA}

At the time when the CLA came into effect, the possession of firearms and ammunition was regulated by the Arms and Ammunition Act 75 of 1969. The Arms and Ammunition Act did not refer to a "semi-automatic firearm" but used the term "arm", which term was comprehensively defined. The Arms and Ammunition Act prescribed a maximum term of three years imprisonment for the unlawful possession of an arm for a first offender, whilst a second or further conviction for the offence could have led to a fiveyear prison term. ${ }^{10}$ In a number of High Court judgments it was held that the minimum sentence provisions provided for in the CLA could not be imposed for a conviction on the offence of the unlawful possession of a semiautomatic fire-arm in terms of the Arms and Ammunition Act. ${ }^{11}$ It was essentially held in those cases that it could not have been the intention of the legislature, when enacting the CLA, that the possession of a pistol for instance, merely because it was a semi-automatic firearm, would attract the prescribed sentence of 15 years' imprisonment. In Motaung $v S^{12}$ a full court of the Free State High Court considered those cases and succinctly summarised the different reasons advanced by the courts for their conclusions. The judgment in Motaung pointed out that some cases held that the Arms and Ammunition Act did not provide for an offence such as the unlawful possession of a semi-automatic firearm. The reference to a semi-automatic firearm in the CLA, being a reference to a non-existent offence, was therefore regarded as an absurdity. ${ }^{13}$ If the provisions of the minimum sentence legislation were to apply in respect of convictions for the unlawful possession of an arm, this would mean that small calibre firearms such as pistols stood to be punished with a minimum sentence of 15 years' imprisonment alongside the possession of the more powerful firearms, when firearms such as revolvers and shotguns, which were of heavier calibre than pistols, did not attract the prescribed minimum sentence. ${ }^{14}$ The

Section 39(b)(1) of the Arms and Ammunition Act 75 of 1969.

S v Sukwazi 20021 SACR 619 (N); S v Khonye 20022 SACR 621 (T); S v Mooleele 20032 SACR 255 (T); and S v Radebe 20062 SACR 604 (O).

Motaung $v$ S 2005 ZAFSHC 130 (18 August 2005).

Motaung $v$ S 2005 ZAFSHC 130 (18 August 2005) para [14].

Motaung v S 2005 ZAFSHC 130 (18 August 2005) para [14]. 
inclusion of the term "semi-automatic firearm" in the CLA was thus an anomaly which the legislature could not have intended. ${ }^{15}$

The Supreme Court of Appeal, in $S v$ Thembalethu, ${ }^{16}$ disapproved of the approach adopted by the different High Courts as described above. The Court held that the wording of the CLA clearly indicates that its provisions supersede all other laws on sentence and apply to all offences listed in the schedules relevant to the CLA, including the offence of possessing a semiautomatic. Kgomo AJA (Mthiyane JA and Malan AJA concurring) held that the wording of the CLA was unambiguous and peremptory. ${ }^{17}$ The court referred to one of its earlier judgments ${ }^{18}$ where it was pointed out that the CLA did not create new offences but referred to specific forms of existing offences for which harsh punishment is decreed. ${ }^{19} \mathrm{Kgomo}$ AJA concluded:

It may well be so that one of the consequences of the Criminal Law Amendment Act is that the unlawful possession of, for example, a pump-action shotgun may entail a more lenient sentence than the unlawful possession of a semi-automatic firearm, this does not result in an absurdity. The singling out of semi-automatic firearms may well have been the result of the frequency with which these firearms have been used in violent crimes. ${ }^{20}$

The court held that the fact that there was no offence under the Arms and Ammunition Act such as the "unlawful possession of a semi-automatic firearm" did not mean that the words of the CLA could not be properly construed. Where it was proved that the "arm" was a "firearm" which was automatic or semi-automatic, the court acquired the enhanced penalty or sentencing jurisdiction. ${ }^{21}$ The court confirmed the minimum sentence of 15 years' imprisonment for the possession of a semi-automatic firearm in contravention of the Arms and Ammunition Act. However, 11 years of the sentence was ordered to be served concurrently with the sentences imposed in respect of the other offences of which the appellant had been convicted. One might have expected that Thembalethu would have settled the matter as far as the minimum sentencing provisions applicable to firearm-related offences are concerned. It did not. Subsequently not all courts agreed that the reasoning in Thembalethu remained valid when the

Motaung $v$ S 2005 ZAFSHC 130 (18 August 2005) paras [12]-[14] with reference to $S$ v Sukwazi 20021 SACR $619(\mathrm{~N})$ and S v Mokomela (TPD) (unreported) case number A751/2002 of 17 February 2003.

$16 S v$ Thembalethu 20083 All SA 417 (SCA).

$17 S v$ Thembalethu 20083 All SA 417 (SCA) para [6].

$18 S$ S Legoa 20031 SACR 13 (SCA).

$19 S v$ Thembalethu 20083 All SA 417 (SCA) para [15].

$20 S$ S Thembalethu 20083 All SA 417 (SCA) para [11].

21 $S v$ Thembalethu 20083 All SA 417 (SCA) para [11]. 
Arms and Ammunition Act was repealed and replaced by the FCA. These developments will be examined below.

\section{The Firearms Control Act and the CLA}

One of the purposes of the FCA is "to enable the State to remove illegally possessed firearms from society, to control the supply, possession, safe storage, transfer and use of firearms and to detect and punish the negligent or criminal use of firearms". ${ }^{22}$ Section 1 of the FCA contains a rather longwinded and highly technical definition of "firearm". It further defines the term "semi-automatic" as "self-loading, but not capable of discharging more than one shot with a single depression of the trigger". ${ }^{23}$

In Motaung, ${ }^{24}$ referred to earlier, the Free State High Court had to consider whether the minimum sentence provisions of the CLA were applicable to the FCA in respect of a semi-automatic firearm. At the time the Thembalethu judgment of the Supreme Court of Appeal, referred to above, had not yet been delivered and it was thus not considered. A full court concluded that the minimum sentence provisions of the CLA did not apply to the unlawful possession of a semi-automatic firearm in terms of the Arms and Ammunition Act and held that the interpretation was equally valid to the application of the CLA to the FCA. ${ }^{25}$

A number of High Courts did, however, have the opportunity to consider whether the reasoning in Thembalethu applied to the FCA as well. Many of them concluded that it did not. In Baartman $v S^{26}$ the Western Cape High Court found that the regulation of semi-automatic firearms under the FCA could not be harmonised with the relevant provisions of the CLA and that the CLA did not apply in sentencing for offences provided for in the FCA. In Baartman the court held that the phrase "notwithstanding any other law" introducing the relevant minimum sentencing provisions of the CLA could never have been intended to override any future statute containing the sentencing provisions such as those provided for in the FCA. ${ }^{27}$ The reasoning in Baartman was followed in some cases of the same division ${ }^{28}$

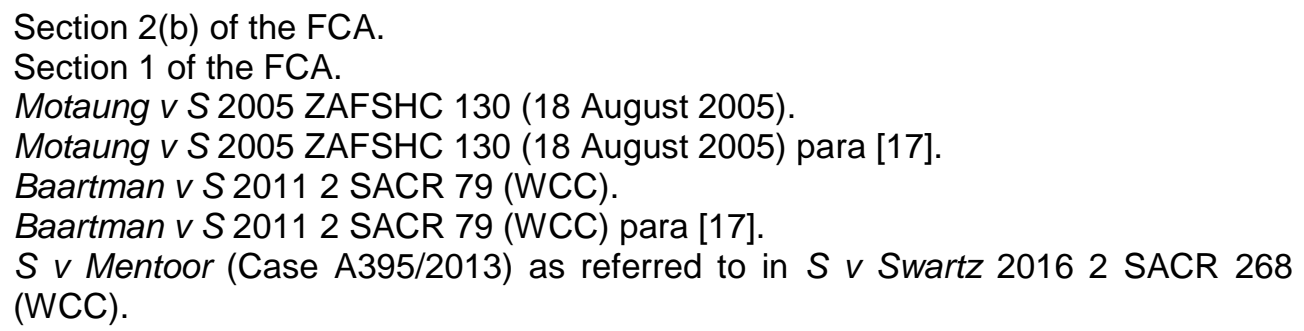


and elsewhere. ${ }^{29}$ In $S v$ Rossouw, ${ }^{30}$ however, the same division of the High Court, seemingly unaware of Baartman, concluded, with reference to Thembalethu, that the relevant prescribed sentencing provisions of the CLA are mandatory. Once it had been proved that an accused had been convicted of the illegal possession of a semi-automatic firearm, this gave rise to the prescribed minimum sentence of 15 years.

In $S v S w a r t z^{31}$ a full court of the Western Cape High Court convincingly refused to follow Baartman. The court advanced a number of reasons for its finding. The reasons included that in terms of Thembalethu the minimum sentences applied when the specific circumstances of an offence brought it within the scope of one of the schedules to the CLA. The wording of the CLA did not permit a distinction between law existing when the CLA came into force and law which had come into existence thereafter. The court further held that, if the intention with the enactment of the FCA had been to repeal (or render inoperative) the provisions of the CLA in relation to semiautomatic and automatic firearms, the legislator would in all probability expressly have dealt with the issue. The issue was once again thoroughly canvassed by two judges of the Western Cape High Court in $S$ v Delport. ${ }^{32}$ The court followed, as it was bound to do, the precedent in Swartz and added that when the FCA was enacted, the prescribed minimum sentence regime in terms of the CLA was a temporary measure that was subject to periodic renewal. This situation possibly explained the inconsonance between the penalty provisions in the CLA and those in the FCA. At the time of adopting the FCA, the legislature presumably would have expected the penalty provisions thereof to stand alone when the "enhancing" effect of the minimum sentencing regime in terms of the CLA Act fell away. The position was altered, however, when the minimum sentences became a permanent feature on the statute book. ${ }^{33}$

In the Eastern Cape Division of the High Court Plasket J, in a judgment critical of the CLA, referred to the arbitrariness of the "bifurcated sentencing regime". ${ }^{34}$ Plasket $\mathrm{J}$ nevertheless found that he was bound by Thembalethu and that the minimum sentence regime found application. Similar

$29 \quad S v$ Motloung 20151 SACR 310 (GJ).

$30 \quad S v$ Rossouw 20141 SACR 390 (WCC). The court had, perhaps unfairly, harsh words for the prosecutor for failing to refer to the minimum sentence provisions in the charge sheet. The prosecutor is, after all, dominus litis and at the time the legal position regarding the application of the CLA to the FCA was far from clear. 
conclusions were reached in other divisions of the High Court. ${ }^{35}$ The matter was finally laid to rest in $S v$ Motloung $^{36}$ in which the Supreme Court of Appeal held that there was no indication that the FCA had intended to repeal the earlier CLA. The court rejected the approach followed in Baartman and approved of the approach followed in Swartz. Motloung thus established that the courts must give effect to the minimum sentencing provisions of the CLA when sentencing offenders convicted for the possession of semiautomatic firearms in terms of the FCA. In Motloung the appellant was not informed in the indictment of the minimum sentence provision for the possession of a semi-automatic firearm and ammunition, nor was he warned about them at the commencement of the trial. As such the trial court did not apply the provisions of the CLA. The Supreme Court of Appeal nevertheless thought it necessary to settle the matter regarding the applicability of the minimum sentencing provisions for a conviction in terms of the FCA. It was thus unnecessary for the court, in the context of the matter, to give guidance on the issue of substantial and compelling circumstances in respect of convictions for firearm-related offences.

Having established that the provisions of the CLA apply to sentencing for the possession of semi-automatic firearms, a brief exposition follows regarding the approach courts should follow when imposing sentences within the framework of the CLA.

\section{The minimum sentence regime}

In $S v$ Malgas $^{37}$ the Supreme Court of Appeal set out in considerable detail the approach to be followed when a court needs to consider an appropriate sentence in terms of the provisions of the CLA. This approach was later endorsed by the Constitutional Court when it upheld the constitutionality of the CLA and found that the sentence must ultimately be proportional if regard is given to all the circumstances of the case. ${ }^{38}$ In Calvin $v S^{39}$ Schoeman AJA pointed out that the usual factors that were taken into consideration when imposing sentence must still be considered in determining whether there are substantial and compelling circumstances

See for example $S v$ Mukwevho 20101 SACR 349 (GSJ); S v Bhadu 20111 SA 487 (ECG); Sukazi v S 2014 ZAGPPHC 728 (16 September 2014); Tau v S 2017 ZAFSHC 42 (23 March 2017); Dlodlo v S 2016 ZAFSHC 18 (18 February 2016); Radebe v S 2017 ZAGPPHC 233 (11 May 2017); and Witbooi v S 2015 ZAWCHC 185 (8 December 2015).

$36 \quad S v$ Motloung 20162 SACR 243 (SCA).

$37 \quad S v$ Malgas 20011 SACR 469 (SCA).

$38 \quad S v$ Dodo 20013 SA 382 (CC).

39 Calvin v The State 2014 ZASCA 145 (26 September 2014). 
present. If the sentencing court is satisfied that the circumstances of the case are such that the prescribed sentence would be unjust in that it would be disproportionate to the crime, the criminal and the needs of society, it may impose a lesser sentence. However, the prescribed, benchmark sentence to be ordinarily imposed for specific crimes should not be departed from for superficial reasons. ${ }^{40}$

In Malgas it was clearly established that the fact that parliament had enacted the minimum sentencing legislation was an indication that it was no longer "business as usual". Courts must approach the question of sentencing, conscious of the fact that the minimum sentence had been ordained as the sentence which should ordinarily be imposed, unless substantial and compelling circumstances are found to be present. ${ }^{41}$ The court held that the legislature aimed at ensuring a "severe, standardised, and consistent response" from the courts to the commission of crimes provided for in the CLA unless there were, and could be seen to be, truly convincing reasons for a different response. ${ }^{42}$

It is against this background that sentencing for firearms-related offences in terms of the minimum sentence regime must also be viewed. ${ }^{43}$ The question arises as to whether a standardised and consistent result, as was envisaged in Malgas, has indeed been achieved in respect of sentencing for the possession of semi-automatic firearms. In order to determine this, an attempt will be made to analyse the sentencing patterns of different divisions of the High Courts, mostly sitting as courts of appeal from matters heard in the Regional Magistrates' Court, in matters involving the possession of semi-automatic firearms. In doing so, the present author is aware that the CLA has been subjected to severe criticism and that its effectiveness in reducing serious crime has been questioned. ${ }^{44}$ It is, however, beyond the scope of this note to revisit this issue.

$40 \quad$ Calvin $v$ The State 2014 ZASCA 145 (26 September 2014) para [8].

$41 \quad S$ v Malgas 20011 SACR 469 (SCA) para [7]; and $S$ v Matyityi 20111 SACR 40 (SCA) para [11].

$42 \quad S v$ Malgas 20011 SACR 469 (SCA) para [11].

$43 \quad S v$ Delport 20162 SACR 281 (WCC) para [38]

44 Cameron

2017

https://www.concourt.org.za/images/phocadownload/justice_cameron/UWC-

Deans-distinguished-lecture-19-October-2017--Minimum-Sentences.pdf; SlothNielsen and Ehlers 2005 SA Crime Quarterly 15-21; Terblanche Guide to Sentencing 90; and Terblanche and Mackenzie 2008 Aust NZ J Criminol 402-420. 


\section{Sentencing patterns in respect of semi-automatic firearms based on the application of the CLA to the FCA}

It is acknowledged that the circumstances pertaining to the crimes and the offender in each of the cases referred to hereunder are unique, and further that courts are obliged to impose individualised sentences. In Nieuwenhuizen $v S^{45}$ the Supreme Court of Appeal stated that it is a healthy practice from a jurisprudential point of view to look at other cases for guidance and not as authority to impose the same sentences imposed in those cases. Each case must still be considered on its own merits. In $S v$ Malgas $^{46}$ the Supreme Court of Appeal referred to the tendency of courts to use, even if only as a starting point, historical sentencing patterns as a provisional standard for comparison when deciding whether a prescribed sentence should be regarded as unjust. With this in mind, the sentencing patterns will be briefly discussed.

In Madikane, ${ }^{47}$ decided in 2011 and referred to earlier, Plasket $\mathrm{J}$ thoroughly analysed the sentencing patterns for the possession of semi-automatic firearms with reference to cases prior to and after the coming into operation of the FCA, including those based on the erroneous interpretation of the interaction between the CLA and firearms legislation. Plasket $\mathrm{J}$ held that he was unable to find any case, apart from Thembalethu which was referred to earlier, in which a sentence of 15 years' imprisonment had been regarded as appropriate. ${ }^{48} \mathrm{He}$ also found that he could find no reported decision by which a sentence exceeding three years' imprisonment was imposed for the possession of a semi-automatic firearm. ${ }^{49}$ Plasket $\mathrm{J}$ held that even if allowance were made for the imposition of more severe sentences for the offence of the unlawful possession of an automatic or semi-automatic firearm as a result of the application of the CLA, a sentence of 15 years' imprisonment was unlikely to be proportional to the crime, the criminal and the legitimate needs of society in all but the most serious of cases. ${ }^{50}$ The court held that it cannot be said that the imposition of the prescribed sentence of 15 years' imprisonment would be just. This fact, in itself, constituted a substantial and compelling circumstance justifying and requiring the court to impose a less severe sentence than the prescribed

$45 \quad$ Nieuwenhuizen v S 2015 ZASCA 90 (29 May 2015) para [13]. See also Terblanche Guide to Sentencing 142-145.

$46 \quad S v$ Malgas 20011 SACR 469 (SCA) para [21].

$47 \quad S$ v Madikane 20112 SACR 11 (ECG).

$48 \quad S$ v Madikane 20112 SACR 11 (ECG) para [24].

$49 S$ v Madikane 20112 SACR 11 (ECG) para [31].

$50 S$ v Madikane 20112 SACR 11 (ECG) para [32]. 
sentence. ${ }^{51}$ A sentence of 7 years' imprisonment was imposed. In $S v$ Dube 52 the same division of the High Court, after having referred to Madikane, confirmed the minimum sentence. The appellant had a previous conviction for the unlawful possession of a firearm. Furthermore, the court considered the fact that the firearm had been used in the execution of wellplanned robbery, the brazen and arrogant conduct of the appellant and his callous disregard for members of the public. ${ }^{53}$

In $S$ v Asma ${ }^{54}$ the Supreme Court of Appeal referred with approval to Madikane when it imposed an 8-year sentence for the possession of a fully automatic firearm, which also resorts under the same minimum sentencing regime. ${ }^{55}$ Shongwe JA found that the minimum sentence was shockingly harsh and disproportionate considering the facts of this case. The unique facts of the case were that at the time when the rifle was found in the appellant's house, he had already been incarcerated. The rifle was not loaded, and no ammunition was found. It further had not been used in the commission of the offences for which he had been arrested. The appellant had failed to proffer a reasonable explanation for the possession save for a bare denial. ${ }^{56}$

In a number of cases the courts did not hesitate to confirm the minimum sentence of 15 years' imprisonment for the unlawful possession of a firearm. In some of those cases the appellants were, however, also charged with other serious offences such as murder and robbery. In such cases scant attention was given to the firearm-related offences as the courts were more concerned with the cumulative effect of the sentences imposed on different counts. In these cases the courts ordered that substantial parts of the minimum sentence either be served with sentences imposed on other counts or that they be suspended. ${ }^{57}$ In Rontlai $v S,{ }^{58}$ for instance, the appellant was convicted of robbery and other offences. The Supreme Court of Appeal, without dealing in any detail with the specific issue, confirmed a

$S$ v Madikane 20112 SACR 11 (ECG) para [32].

$S v$ Dube 20122 SACR 579 (ECG).

$S v$ Dube 20122 SACR 579 (ECG) para [9].

$S v$ Asmal 2015 ZASCA 122 (17 September 2015).

$S v$ Asmal 2015 ZASCA 122 (17 September 2015) para [6].

$S v$ Asmal 2015 ZASCA 122 (17 September 2015) para [10].

57 Mchunu v S 2017 ZAGPJHC 252 (12 September 2017); Sibande v S 2017 ZAGPPHC 754 (10 November 2017); and Rontlai v S 20181 SACR 1 (SCA). In Luvuno v S 2018 ZAGPJHC 591 (2 November 2018) the high court on appeal imposed a globular sentence of 15 years' imprisonment for murder and the unlawful possession of a semi-automatic firearm. The judgment gave very little attention to the firearms offence. 
sentence of imprisonment of 15 years in respect of the unlawful possession of a semi-automatic firearm, of which 11 years were wholly suspended. The appellant was sentenced to an effective term of 20 years' imprisonment for two robberies and the possession charge. In Sibande $v S^{59}$ the High Court, relying on Thembalethu, confirmed the prescribed sentence of 15 years' imprisonment for the unlawful possession of a semi-automatic firearm. The court held that the appellant's attempt to distance himself from any possession of the semi-automatic firearm and his denial of any knowledge thereof, coupled with his illegal presence in South Africa, outweighed his personal circumstances. ${ }^{60}$

In Dladla $v S^{61}$ the 45-year-old appellant was sentenced to 15 years' imprisonment for the unlawful possession of a semi-automatic firearm with the serial number obliterated and the unlawful possession of ammunition as well as 15 years for the unlawful possession of 30 rounds of ammunition. On appeal it was held that answers to questions as to how he acquired the firearm, for what purpose and what he intended to do with it were to be given by the defence. The court held that regardless of the serious nature of the offence, the appellant was a good candidate for rehabilitation as he was a first offender. The High Court, perhaps erring on the side of leniency, imposed a singular sentence of 5 years' imprisonment in respect of both counts, two years of which were conditionally suspended. This sentence was imposed notwithstanding the fact that the appellant had been convicted for the unlawful possession of a prohibited firearm, namely a semi-automatic rifle, with the serial number obliterated. It seems that in this case the court lost sight of the benchmark set by the legislator.

Recent jurisprudence points strongly to the fact that, even upon a finding of the existence of substantial and compelling circumstances, courts regard the deterrence of firearm-related offences in a serious light and intend to send a message that it is indeed not business as usual. The judgment in $S$ $v$ Molahi, ${ }^{62}$ for instance, emphasised the need to deter firearms-related offences and a sentence of 8 years' imprisonment was imposed for the unlawful possession of a semi-automatic firearm. This sentence and sentences imposed on different other counts were ordered to run concurrently with a 15-year sentence for robbery. The court stated:

\footnotetext{
$59 \quad$ Sibande $v$ S 2017 ZAGPPHC 754 (10 November 2017).

60 Sibande v S 2017 ZAGPPHC 754 (10 November 2017) para [15].

$61 \quad$ Dladla $v$ S 2016 ZAKZPHC 74 (25 August 2016).

$62 S$ v Molahi 2016 ZAGPJHC 74 (21 April 2016).
} 
On a more frequent basis, crimes in this country are committed using illegal firearms. In fact, the proliferation of illegal firearms throughout the country has contributed to the high incidents of violent crime. The frequent use of illegal firearms in the commission of violent offences has contributed to the fear that members of the community live with. They fear driving and stopping their cars in remote places as they may become victims of crime. The behaviour of the accused and others like him, impacts negatively on the quality of freedom of all living in South Africa. ${ }^{63}$

Similar sentiments were expressed in numerous other cases. In Witbooi $v$ $S^{64}$ the court confirmed a sentence of 10 years imprisonment of which two years were suspended on certain conditions. The court emphasised the gravity of the offence and held that severe sentences were called for due to the fact that there had been no-let up in the crime pandemic engulfing South Africa. The court found that the introduction of minimum sentence legislation in respect of the illegal possession of automatic or semi-automatic firearms was directly related to the frequency with which illegal firearms had been used in perpetrating violent crimes. The court held that when the sentences imposed in Thembalethu and other cases were considered, "the overwhelming view appears to be that our courts will not hesitate to impose the sentences as prescribed by the legislature in cases relating to the unlawful possession of automatic and semi-automatic firearms". ${ }^{65}$ Although the court regarded the sentences imposed by the magistrate as appearing to be "on the steep side", it did not find it unduly harsh. ${ }^{66}$

In Dlodlo $v S^{67}$ the appellant was sentenced in the regional court to nine years and three years' imprisonment for the unlawful possession of a firearm and for the unlawful possession of ammunition. On appeal to the Free State High Court, it was held that the sentence was unduly harsh. The court found that the magistrate had placed too much reliance on the prevalence of the crime, the interests of society and the seriousness of the crime in question in relation to the personal circumstances of the appellant as a first offender, his having spent a lengthy time in prison, and the circumstances of the crime. ${ }^{68}$ The sentences were replaced with six years and three years' imprisonment, to be served concurrently. ${ }^{69}$ In Tau $v S{ }^{70}$ also emanating from the Free State High Court, the appellant was sentenced to 8 years' imprisonment by a District Court after having been found in the unlawful

\footnotetext{
$63 S$ v Molahi 2016 ZAGPJHC 74 (21 April 2016) para [10].

$64 \quad$ Witbooi v S 2015 ZAWCHC 185 (8 December 2015).

$65 \quad$ Witbooi $v$ S 2015 ZAWCHC 185 (8 December 2015) para [11].

$66 \quad$ Witbooi v S 2015 ZAWCHC 185 (8 December 2015) para [17].

67 Dlodlo v S 2016 ZAFSHC 18 (18 February 2016).

68 Dlodlo v S 2016 ZAFSHC 18 (18 February 2016) para [11].

69 Dlodlo v S 2016 ZAFSHC 18 (18 February 2016) para [13].

$70 \quad$ Tau v S 2017 ZAFSHC 42 (23 March 2017).
} 
possession of a firearm. The offence was not accompanied by other crimes. Although a District Court may not impose the sentences in terms of the CLA, it does have, as was pointed out earlier, enhanced penal jurisdiction in terms of the FCA. In a brief judgment the sentence was upheld on appeal.

In Mokhobo $v S^{71}$ the appellant, upon a plea of guilty was convicted of theft, the unlawful possession of a semi-automatic pistol and one count of the possession of ammunition. He was sentenced to 10 years' imprisonment for the possession of the firearm. His effective sentence was 12 years' imprisonment. The Free State High Court was rather sceptical of the magistrate's decision to impose a lesser sentence than the prescribed sentence. Lekale $\mathrm{J}$ held that the trial court:72

[a]pparently found reason to deviate from the prescribed minimum sentence of 15 years' imprisonment for unlawful possession of a semi-automatic firearm but did not specifically record its reasons for so doing.

The court found, however, that it could be inferred that the magistrate had relied upon the fact that there was no evidence that the firearm had been used to commit any violent crimes whilst in the appellant's possession. Lekale $\mathrm{J}$ held, however, that had the firearm been used to commit such crimes, the appellant would most probably have been charged for those crimes and, if convicted, been sentenced accordingly and added that "[on] a charge and conviction of unlawful possession of a firearm the accused gets sentenced for possession as convicted and nothing else". ${ }^{73}$

The approach followed in $S \vee S w a r t z^{74}$ regarding the grading of the seriousness of offences is instructive. Rogers $\mathrm{J}$, writing for the full court, found that crimes such as rape and robbery with aggravating circumstances cover a wide range of criminal conduct. In those cases the criminal conduct itself can be regarded as lying on a continuum from the less serious to the truly heinous. The court held that it is more difficult to view the unlawful possession of an automatic or semi-automatic firearm in this way. The legislator required that in the absence of substantial and compelling circumstances, a first offender should be sentenced to 15 years' imprisonment. If the accused person is also convicted of a crime relating to the use of a firearm (for example murder), he would be sentenced separately for that crime. ${ }^{75}$ The court concluded that in the absence of

Mokhobo v S 2017 ZAFSHC 104 (15 June 2017).

Mokhobo v S 2017 ZAFSHC 104 (15 June 2017) para [8]

Mokhobo v S 2017 ZAFSHC 104 (15 June 2017) para [8].

$S v$ Swartz 20162 SACR 268 (WCC).

$S$ v Swartz 20162 SACR 268 (WCC) para [42]. 
special circumstances explaining how the unlawful possession came about or in the absence of compelling personal circumstances of the accused, it was bound to impose the minimum sentence. The unlawful possession of a semi-automatic firearm could not in itself be regarded as not justifying the prescribed 15-year sentence. ${ }^{76}$

In Swartz the appellant was convicted on two counts of the unlawful possession of a semi-automatic firearm. The court confirmed the minimum sentence of 15 years on one of the counts, in view of the fact that the appellant had offered a denial of possession, which denial was found to be false, and furthermore that no mitigating circumstances in relation to his possession could be inferred. The court held that there was nothing to place his unlawful possession of the firearm in a less heinous light than that which motivated the lawmaker to lay down a minimum 15-year sentence. ${ }^{77}$ However, on the further count of the unlawful possession of a semiautomatic firearm, the appeal against the minimum sentence imposed was upheld and replaced with a sentence of seven year's imprisonment. In this regard the court held that the state accepted the appellant's version to the effect that he fortuitously came across the firearm in a rubbish dump and was apprehended the same day. The appellant's decision to take the firearm into his possession could be regarded as having been made on the spur of the moment. Furthermore, it was found that the appellant did not have the firearm in his possession for very long before he was apprehended. ${ }^{78}$ The court held that the circumstances of the crime were such as to make a sentence of 15 years' imprisonment disproportionate.

A similar sentiment was expressed in $S v$ Delport. ${ }^{79}$ Although dealing with a fully automatic firearm, Binns-Ward $J$ expressed reservations about the suggestion in some judgments that the possession of an unlicensed firearm should be treated as serious only if the weapon had been used for the commission of a serious crime. The court held that offenders who use the weapons to commit other serious crimes fall to be punished separately for those crimes. In such matters it is the cumulative effect of the sentences imposed, rather than whether a heavier sentence should be imposed for the unlawful possession of the firearm, which should be the more relevant consideration. ${ }^{80}$ The court found no substantial and compelling circumstances to justify the imposition of a sentence lesser than the

$S$ v Swartz 20162 SACR 268 (WCC) para [42].

$S v$ Swartz 20162 SACR 268 (WCC) para [43].

$S v$ Swartz 20162 SACR 268 (WCC) para [44].

$S v$ Delport 20162 SACR 281 (WCC).

$S v$ Delport 20162 SACR 281 (WCC) para [35]. 
prescribed minimum. The court noted the following aggravating features: the weapon was a prohibited weapon; it was heavily loaded with live ammunition; the erasure of its serial number suggested that it had probably been stolen; and the fact that it was discovered in a stolen motor vehicle fitted with false number plates was indicative of its probably having been possessed for criminal purposes. The court held that it was difficult to conceive of any criminal activity, other than illicit trading, in which a fully automatic firearm would serve any purpose other than one involving violence or the threat of it. ${ }^{81}$

\section{Conclusion}

The legislature has deemed the possession of a semi-automatic firearm in such a serious light that it was singled out for harsh punishment. The prescribed sentences should ordinarily be imposed unless substantial and compelling circumstances are found to be present. ${ }^{82}$ In Motloung the Supreme Court of Appeal finally confirmed that the minimum sentence regime applies to firearms offences under the FCA. In both Thembalethu and Rontlai the Supreme Court of Appeal upheld the minimum sentence for the possession of a semi-automatic firearm. From the Supreme Court of Appeal's judgment in Asmal it appears that the circumstances under which the unlawful possession occurred and the purpose for which the semiautomatic firearm was possessed will play a pivotal role in determining whether substantial and compelling circumstances justifying the imposition of a lesser sentence exist. As was pointed out in Delport there will still be a gradation of seriousness attached to the unlawful possession of firearms. The grading of the offence will typically be informed by the risk of harmfulness and the culpability of the offender. ${ }^{83}$ Regarding the question whether the fact that no further crimes were committed with the firearm in question should have an impact on the decision on whether substantial and compelling circumstances exist, it seems that the courts increasingly favour the approach that offenders who used the firearm to commit other serious crimes should be punished separately for those crimes so as not to detract from the objective gravity of firearms offences singled out in the CLA. From the investigation it is evident that courts are more likely to impose the minimum sentence in cases where the accused is also convicted of other serious offences such as murder and robbery. In such cases little attention

\footnotetext{
$81 S$ S v Delport 20162 SACR 281 (WCC) para [40].

$82 S$ V Malgas 20011 SACR 469 (SCA) para [8]; and $S v$ Matyityi 20111 SACR 40 (SCA) para [12]. 
is given to the firearm-related offences as the courts are more concerned with the cumulative effect of sentences imposed on different counts. In cases where the accused is convicted of the stand-alone offence of the unlawful possession of a semi-automatic firearm, the courts are taking an increasingly unsympathetic stance towards offenders, and terms of imprisonment in the range of 7 to 10 years' imprisonment are commonly imposed. In addition to the accused's personal circumstances, one of the most important factors in deciding on an appropriate sentence is the explanation of how the unlawful possession came about. It seems that the judicial sentiment increasingly does not support the view that the possession of an unlicensed firearm should be treated as serious only if the weapon has been used for the commission of a serious crime.

\section{Bibliography}

\section{Literature}

Sloth-Nielsen and Ehlers 2005 SA Crime Quarterly

Sloth-Nielsen $\mathrm{J}$ and Ehlers $\mathrm{L}$ "Assessing the Impact: Mandatory and Minimum Sentences in South Africa" 2005 SA Crime Quarterly 15-21

Terblanche Guide to Sentencing

Terblanche S A Guide to Sentencing in South Africa $3^{\text {rd }}$ ed (LexisNexis Durban 2016)

Terblanche and Mackenzie 2008 Aust NZ J Criminol

Terblanche $S$ and Mackenzie $G$ "Mandatory Sentences in South Africa: Lessons for Australia?" 2008 Aust NZ J Criminol 402-420

\section{Case law}

Baartman v S 20112 SACR 79 (WCC)

Calvin v The State 2014 ZASCA 145 (26 September 2014)

Dladla v S 2016 ZAKZPHC 74 (25 August 2016)

Dlodlo v S 2016 ZAFSHC 18 (18 February 2016)

Luvuno v S 2018 ZAGPJHC 591 (2 November 2018)

Mchunu v S 2017 ZAGPJHC 252 (12 September 2017)

Mokhobo v S 2017 ZAFSHC 104 (15 June 2017) 
Motaung v S 2005 ZAFSHC 130 (18 August 2005)

Nieuwenhuizen v S 2015 ZASCA 90 (29 May 2015)

Radebe v S 2017 ZAGPPHC 233 (11 May 2017)

Rontlai v S 20181 SACR 1 (SCA)

S v Asmal 2015 ZASCA 122 (17 September 2015)

S v Bhadu 20111 SA 487 (ECG)

S v Delport 20162 SACR 281 (WCC)

$S$ v Dodo 20013 SA 382 (CC)

S v Dube 20122 SACR 579 (ECG)

$S v$ Khonye 20022 SACR $621(\mathrm{~T})$

$S v$ Legoa 20031 SACR 13 (SCA)

S v Madikane 20112 SACR 11 (ECG)

$S$ v Malgas 20011 SACR 469 (SCA)

S v Matyityi 20111 SACR 40 (SCA)

S v Molahi 2016 ZAGPJHC 74 (21 April 2016)

$S v$ Mokomela (TPD) (unreported) case number A751/2002 of 17 February 2003

$S$ v Mooleele 20032 SACR 255 (T)

S v Motloung 20151 SACR 310 (GJ)

S v Motloung 20162 SACR 243 (SCA)

S v Mukwevho 20101 SACR 349 (GSJ)

$S$ v Radebe 20062 SACR 604 (O)

$S v$ Rossouw 20141 SACR 390 (WCC)

S v Sukwazi 20021 SACR $619(\mathrm{~N})$ 
S v Swartz 20162 SACR 268 (WCC)

S v Thembalethu 20083 All SA 417 (SCA)

Sibande v S 2017 ZAGPPHC 754 (10 November 2017)

Sukazi v S 2014 ZAGPPHC 728 (16 September 2014)

Tau v S 2017 ZAFSHC 42 (23 March 2017)

Witbooi v S 2015 ZAWCHC 185 (8 December 2015)

\section{Legislation}

Arms and Ammunition Act 75 of 1969

Criminal Law Amendment Act 105 of 1997

Firearms Control Act 60 of 2000

Magistrates' Court Act 32 of 1944

\section{Internet source}

Cameron 2017 https://www.concourt.org.za/images/phocadownload/ justice_cameron/UWC-Deans-distinguished-lecture-19-October-2017-Minimum-Sentences.pdf

Cameron E 2017 Imprisoning the Nation: Minimum Sentences in South Africa - University of the Western Cape, Faculty of Law: Dean's Distinguished Lecture https://www.concourt.org.za/images/phoca download/justice_cameron/UWC-Deans-distinguished-lecture-19-October2017--Minimum-Sentences.pdf accessed 4 April 2019

\section{List of Abbreviations}

Aust NZ J Criminol

CLA

FAC
Australian and New Zealand Journal of Criminology

Criminal Law Amendment Act 105 of 1997

Firearms Control Act 60 of 2000 